\title{
Politische Gemeinwohl-Diskurse in Großbritannien: von den ,Rosenkriegen“ zum Bürgerkrieg
}

,Gemeinwohl` und ,Gemeinsinn“ können als Korrespondenzbegriffe verstanden werden, die zum einen die objektive und zum anderen die subjektive Dimension einer reziproken Beziehung zwischen Individuum und Gemeinschaft bezeichnen. Das Individuum versteht sich kognitiv und emotional als Teil einer Gemeinschaft, für die es sich normativ verpflichtet weiß, Leistungen, Opfer zu erbringen, so wie es sich reziprok, jedenfalls als Norm, durch die Gemeinschaft und ihre anderen Mitglieder akzeptiert, angenommen und in ihrer Sorge aufgehoben weiß. Wenn und solange diese reziproke Beziehung problemlos funktioniert, wird sie wahrscheinlich nicht thematisch. Es gibt kaum Gründe, über ,Gemeinwohl' und ,Gemeinsinn` zu sprechen, solange deren allseitig reziproke Existenz selbstverständlich vorausgesetzt werden kann. Die Tatsache, daß es zu einer gegebenen Zeit einen ,Gemeinwohl'-Diskurs gibt, verweist bereits auf Probleme des ,Gemeinwohls', die in Defizienzbegriffen wie ,Egoismus', ,Eigennutz' oder ,Korruption“ formuliert werden. Gemeinwohldiskurse zeigen das Fehlen von Konsens über das Gemeinwohl an, der über Auseinandersetzungen, diskursiv, politisch, eventuell gewaltsam hergestellt wird. Politisch wird dieser Streit, wenn er sich mit Fragen der Macht, des Verhältnisses von Regierenden und Regierten verknüpft. Auch der Bürgerkrieg - offensichtlich Signatur eines gescheiterten, zerbrochenen Gemeinwohls - wird diskursiv im Horizont strittiger Gemeinwohlsemantik ausgetragen, die im Rahmen ideologischer, politischer und militärischer Mobilisierung die Bürger aus bequemer Selbstbezogenheit, Privatheit, herausreißt. Die Anrufung des Gemeinwohls kann dabei eine Legitimationsstrategie sein, der eigenen Partei das Gemeinwohl zu vindizieren und es der Gegenseite zu bestreiten, sie kann ein Aufruf zur Mäßigung, zum Kompromiß sein oder schließlich einen internen Mobilisierungsdiskurs darstellen. Jedenfalls erhellt, daß sich der Sinn einer Gemeinwohl-Semantik aus den polemischen Frontstellungen erschließt.

Im folgenden soll die britische Geschichte politischen Denkens von der Mitte des 15 . bis zum Ausbruch des Bürgerkrieges im 17. Jahrhunderts auf signifikante Konjunkturen der,Gemeinwohl'-Semantik hin befragt werden. Die Darstellung folgt der Chronologie. Die herangezogenen Autoren und Texte sollen als repräsentativ für politische Strömungen gelten, ohne daß hier die Diskursstrukturen und Gewichtungen umfassend analy- 
siert werden könnten. Das übergreifende Interesse gilt dem Spannungsverhältnis zwischen substanziellen und formal-institutionellen Aspekten von ,Gemeinwohl'Diskursen. Ist ,Gemeinwohl' elementar stets inhaltlich bestimmt, so drängt sich in den Konflikten über das ,Gemeinwohl' in politischen Kontexten alsbald der Gedanke der Neutralisierung inhaltlicher Differenzen über das ,Gemeinwohl' durch die reflexive Verschiebung in institutionalisierte Verfahren der Konsensbildung auf, ohne daß damit die inhaltliche Bestimmung vollständig verdrängt wäre. Und meine These lautet, daß die Formalisierung des, Gemeinwohls' nicht unumkehrbar, nicht linear und nicht endgültig sein kann, da auch noch Verfahren der ,Gemeinwohl'-Bestimmung auf substanzielle Konsensbestände angewiesen bleiben. In diesem Sinne wird in den Abschnitten 1 und 2 die Ausbildung des, Gemeinwohl'-Begriff zu einem legitimatorischen Schlüsselbegriff aufgezeigt, an den sich zunächst schwache Institutionalisierungsvorschläge knüpfen. Mit dem Eindringen protestantischer, ,innerweltlicher` Religiosität (Max Weber) in die politischen Diskurse findet dann - so das Argument im 3. Abschnitt - eine substanzialistische Aufladung des ,Gemeinwohls' statt. Im 4. Abschnitt wird die historisch daran anknüpfende Ableitung von Forderungen zur Institutionalisierung des ,Gemeinwohls' aus der Idee des Widerstandsrechts gezeigt. Der 5. Abschnitt dient der Darstellung der Legitimationskonkurrenz zwischen Krone und Parlament im frühen 17. Jahrhundert und der parallel stattfindenden Öffnung der Diskursräume, in denen das ,Gemeinwohl' verhandelt wird. In Abschnitt 6 schließlich wird die These übergesetzlicher Definitionsmacht des ,Gemeinwohls' durch das Parlament, auch ohne und gegen den König, rekonstruiert. ${ }^{1}$

\section{Die ,Rosenkriege' und das ,Dominium politicum et regale ${ }^{6}$}

David Starkey hat gezeigt, daß der Begriff ,Commonwealth', wohl das wichtigste englische Äquivalent für ,Gemeinwohl' in der frühen Neuzeit, etwa ab der Mitte des 15. Jahrhunderts schrittweise und in bestimmten Konjunkturen in den Rang eines zentralen Legitimationsbegriffes einrückt. ${ }^{2}$ So wurde im Protokoll einer Sitzung des Kronrats zu dieser Zeit der Grundsatz formuliert, daß politisches Handeln, „If it be in prejudice of comune wele, it is unlawfull", und in einer Parlamentsberatung einige Jahre später findet sich die normative Formel, man wolle „Avaunce and further the Kynges welfare and his Roiall estate, and the comune welle". ${ }^{3}$ Die Konstellation der ,Rosenkriege", die Konkurrenz der Dynastien der Lancaster und York um den englischen Thron, dramatisierte diesen Diskurs. In der Folge der militärischen Niederlage Henrys VI. von Lancaster im Streit um die Normandie, 1450, klagte das Parlament den führenden Minister, den Duke of Suffolk an, zum Verräter geworden zu sein „of this your realm for the common weal of the same“. ${ }^{4}$ Die bäuerlichen Rebellen von Kent, die sich in dieser

\footnotetext{
1 Im folgenden nutze ich gelegentlich auch Material aus meinem Aufsatz zum Commonwealth (Ottow 2000).

2 Vgl. Starkey 1986

3 Vgl. Kurath 1959, Stichwort: Common weal.

4 Zitiert nach Starkey 1986, S. 19.
} 
politischen Krisensituation unter der Führung Jack Cades erhoben hatten, kamen nach dem Bericht eines zeitgenössischen Chronisten nach London „for the comyn wele of the realm of Ingolande" . 5 Erscheint der Begriff dann in Erklärungen des Herzogs von York, so wird in der Antwort der Königsseite deutlich, daß mit dem Begriff ,Commonwealth ${ }^{6}$ Politik zu machen war, denn der Streit ging darum, welche der dynastischen Parteien für sich beanspruchen kann, das ,Common Weal' zu repräsentieren. Die Yorkisten, so wird dort argumentiert, geben vor „,under untrue, feigned and pretenced colours of intending to the commonweal of this our land, whereas God knoweth the intent of those that so labour is to the subversion thereof ${ }^{\prime \prime} .{ }^{6}$ Diese polemische Bedeutung des Begriffs im Konflikt der rivalisierenden Dynastien steigert sich, als um 1459 die Yorkisten eine neue Offensive beginnen und, um dem Stigma einer Privatverschwörung zu entgehen, gegenüber dem König erklären, ihr Ziel sei ,the prosperity and augmentation of your high estate, and [...] the common weal of this realm". ${ }^{\text {. }}$

Gehörte die Idee der Einbindung der Königsmacht in verbindliche Beratungskontexte zu den mittelalterlichen Traditionsbeständen englischen politischen Denkens, so erfährt dieser Gedanke in Texten Sir John Fortescues nun eine einflussreich nachwirkende Verstärkung und Systematisierung. Fortescue war als Oberrichter, Mitglied des Kronrates und schließlich als Lordkanzler Henrys VI. in den 1460er Jahren in die Konvulsionen der ,Rosenkriege' involviert. In seinen beiden wichtigsten politiktheoretischen Schriften: De laudibus legum Angliae, sowie Of the Governance of England bestimmt Fortescue die englische Monarchie im Gegensatz zu Frankreich, wo Fortescue ein frühabsolutistisches reines Dominium regale sieht, als ein Dominium politicum et regale, d.h. daß dem monarchischen Regiment eine starke Repräsentativkomponente in Gestalt vor allem des Parlaments beigeordnet ist. ${ }^{8}$ Generell formuliert Fortescue die normative Verpflichtung des englischen Königs, sich durch den Hochadel, durch seinen Kronrat und durch das Parlament beraten zu lassen, und aus dieser Einbindung verschiedener Schichten und Gruppen in politische Entscheidungsprozesse soll die englische Monarchie ihre eigentümliche Stärke beziehen. Der potentielle Gegensatz von Regierenden und Regierten wird durch die Selbstbindung der Bürger, direkt oder durch Repräsentanten im Parlament, das als Ort virtueller Repräsentation des gesamten Gemeinwesens verstanden wird, entschärft. Seine höchste Autorität genießt der König daher als ,King in Parliament ${ }^{*}$. Die damit einflußreich etablierte Idee des ,Government by Consent ${ }^{\circ}$ kann als Grundnote der englischen politischen Kultur der kommenden Jahrhunderte verstanden werden. Sie impliziert, daß die legitime Geltung politischer GemeinwohlKonzeptionen nicht den Wagnissen eines stets erneuerten politischen Streits überlassen bleibt, sondern in der Institutionalisierung von Beratung und Konsens durch verbindliche Verfahren gesichert wird.

\footnotetext{
5 Murray 1893, s.v.: Common weal, Commonweal; Starkey 1986, S. 19.

${ }^{6}$ Starkey 1986, S. 20.

7 Holinshed et al. 1808, Bd. 3, S. 254-8; Starkey 1986, S. 21.

8 Fortescue 1997.
} 


\section{Präreformatorischer Humanismus}

Mit dem Eindringen des Humanismus in England verbindet sich der ,Commonwealth"Begriff mit jenem der ,Res publica' und meint seit Mitte des 16. Jahrhunderts, wie jener, sowohl das politische Gemeinwesen als solches wie auch das Gemeinwohl: Staat und Gemeinwohl werden normativ gleichgesetzt. ${ }^{9}$

Thomas More liefert in seiner Utopia sowohl eine Kritik der herrschenden politischen Verhältnisse, die manifest gegen das Gemeinwohl verstoßen, als auch, in der eigentlichen Utopie, einen positiven Gegenentwurf, in dem ein humanistisch verstandenes Gemeinwohl realisiert gedacht wird. Die ,noble men and gentlemen, yea, and certeyn Abbottes, holy men" werden, in der Sprache der frühesten englischen Übertragung der Schrift von 1551, angeklagt, sich nicht mit ihren Grundrenten zufriedenzugeben, nicht damit, ,that they live in rest and pleasure, nothyng profything, ye, muche noyinge the weale publique", sondern die Bauern durch Einhegungen ihrer Felder zu berauben. Sie ,enclose all in pastures; [...] plucke downe townes; and leave nothing stondynge but only the churche, to make of it a shepehowse ${ }^{\text {". }}{ }^{10}$ Wenn diese Agrarkapitalisten die Landbevölkerung vertreiben und so brot- und heimatlos gewordene Scharen umherziehender Bettler erzeugen, dann ist dies eine mindestens dem Umfang nach neue Erscheinung der englischen Sozialgeschichte, die einen wesentlichen Hintergrund für die Utopia und die darin verarbeitete Krisenwahrnehmung bildet. More konstatiert hier eine moralische Transformation, die wesentlich durch die Sprengung der ,Commonwealth Idee definiert ist, soweit in ihr das allgemeine Wohl als soziomoralische Verpflichtung normativ im Handeln der Eliten inkorporiert ist.

Ein anderer Aspekt des Gemeinwohls kommt in der Utopia bei der Auseinandersetzung mit der humanistischen Idee der, Vita activa' zum Tragen, wo nämlich der von den ,Utopiern' berichtende Reisende aufgefordert wird, ,that you maie apply your wytte and delygence to the proffyt of the weale publyque, though it be sume what to youre owne payne and hyndraunce" (S. 9, 30). Dieser jedoch verweist auf die an den europäischen Höfen vorherrschenden politischen Konzeptionen, die die Bereicherung der Krone auf Kosten der Verelendung des Volkes befürworten, obwohl normativ gelte, daß "the comminaltie chooseth their king for their owne sake and not for his sake; for this intent that through his labour and studie they might al live wealthily, safe from wronges and iniuries". In antiker Tradition unterscheidet More den König vom Tyrannen durch die instrumentelle Unterordnung unter das Gemeinwohl; wesentlich dadurch erwirbt der König wahre ,Majestät' (S. 36f.). Diese in der Fürstenspiegelliteratur der Zeit verankerte Norm fürstlichen Regiments verbindet er vermittels der Wahl des Königs durch das Volk mit einer Verfahrenskomponente, die wahre Majestät erst sichert.

Mores Blick auf die tatsächlichen Verhältnisse in Europa zeigt ihm jedoch eine Gesellschaft, die tiefgreifend durch das Privateigentum korrumpiert ist, und er gelangt daher zu dem Schluß: Privateigentum als soziales Strukturprinzip und Gemeinwohl schließen sich aus. Wenn ihm der Staat der Utopier als der einzige gilt, der ,alone of good ryght may clayme and take upon it the name of a common wealthe or publyque

9 Elton 1990; Jones 1998.

${ }^{10}$ More 1952, S. 16. Die im Text folgenden Seitenangaben beziehen sich auf diesen Text. 
weale“, so weil überall sonst zwar das Gemeinwohl angerufen wird, „but everye man procureth hys owne pryvate wealthe". Die Rede vom ,Gemeinwohl" erweist sich als Strategie zur Verschleierung von Privatinteressen. Staaten, in denen dies der Fall ist, gelten More - nach dem berühmtem Wort - als ,a certein conspiracy of riche men, procuringe theire owne commodities under the name and title of the common wealth" (S. 138ff.). Die Reflektion schaut hinter die Rhetorik und prüft die Interessen, denen diese dient, und decouvriert dadurch den strategischen Charakter der GemeinwohlRhetorik.

Die ,Gemeinwohl'-Idee und ihre Pervertierung organisiert auch die Hauptschrift des englischen Humanisten Thomas Starkey: A Dialogue between Pole and Lupset, die etwa 1530 entstand, allerdings zeitgenössisch nur als Manuskript zirkulierte. ${ }^{11}$ Das ,Gemeinwohl', so Starkey, sei zwar in aller Munde, doch werde nicht wirklich verstanden, worin es eigentlich besteht (S. 19). Denn wenn die Menschen sich wahrhaft dem Gemeinwohl verpflichtet fühlten, ,they wold not so lytyl regard yt as they do, they wold not so hyly extyme theyr owne pryvat plesure \& wele" (S. 22). Worin besteht das richtig verstandene Gemeinwohl? Um den Gegensatz von Privatwohl und Gemeinwohl aufzulösen, definiert Starkey das Gemeinwohl zunächst durch das Private und dessen Summe (S. 22), doch nur soweit das Privatwohl nicht verabsolutiert, sondern gleichsam stets mit Blick auf das Gemeinwohl verfolgt wird, denn die Menschen müßten verstehen, ,that when they loke to the commyn profyt, that they therwyth also regard theyr owne, syngular \& pryvate“. Das Gemeinwohl ,shold be fyxyd in theyr hartys, yt schold be the end of al theyr cogytatyons, conseyls \& cares" (S. 45). Um diesen Gedanken plausibel zu machen, vergleicht Starkey in einer organologischen Analogie das politische Gemeinwesen mit dem menschlichen Körper, wobei die Seele politisch repräsentiert sei durch „cyvyle ordur \& polytyke law, admynystryd by offycers \& rulars“ (S. 31). Und die Stärke dieses politischen Wesens hänge von der richtigen Proportion, Zuordnung und Funktion seiner Teile ab, die, jenseits ihrer spezifisch besonderen Aufgaben, auf das Gemeinwohl hingeordnet sein müssen; das ist in erster Linie die Aufgabe der Regierenden,, denen Gemeinsinn-Dispositionen auf Seiten der Regierten jedoch entgegenzukommen haben.

Auf die Regimeform: Monarchie, Aristokratie oder Demokratie kommt es solange nicht an, wie die Regierenden nicht das eigene Wohl, sondern das Gemeinwohl verfolgen und solange die Teile des Gemeinwesens ihre Pflicht als Teil des Gemeinwesens tun. Auch die Regierenden müssen verstehen, daß und wie ihr Wohl mit dem des Gemeinwesens zusammenhängt, so wie auch der Steuermann, der sein Schiff durch Nachlässigkeit auf einen Felsen steuert, umkommt, während jener, der es aus dem Sturm in den Hafen rettet, nicht nur die Passagiere, sondern auch sich selbst rettet. Niemand kann "long enyoy plesure or quyetnes, where the whole ys dysturbyd \& put out of ordur", und darin liege der Beweis, ,that in the regard ever of the true \& commyn wele, ys conteynyd also the regard of the pryvate [... $]^{\text {"s }}$ (S. 46). Tatsächlich jedoch sieht die herrschende Schicht, nach Starkey, „, chefely to theyr owne profyte, plesure \& commodyte, $\&$ few ther be wych regard the welth of the commynalty, but under the pretense \&

1 Starkey 1989; vgl. Mayer 1989; 1992. Die im Text folgenden Seitenangaben beziehen sich auf Starkey 1989. 
colure therof every one of them procuryth the pryvate $\&$ the syngular wele. "Das gelte für Fürsten und Adlige genauso wie für Bischöfe und Prälaten, aber auch dem gemeinen Volk fehle es an Gemeinsinn.

Das wesentliche Mittel zur Behebung dieses radikalen Übels sieht Starkey in einem kulturellen Programm moralischer Erneuerung, das er etwa durch Rückgriff auf die antike römische Institution der Zensoren als Sittenwächter, als „,conservaterys of the commyn wele", zu befördern vorschlägt, welchen er auch die Aufgabe der Überwachung der politischen Magistrate zuweist (S. 136). Daneben treten Überlegungen zur institutionellen Einbindung der Monarchie in Beratungs- und Konsensgremien, die verhindern sollen, daß das politische Zentrum - die Krone, der Hof - sich von den Interessen, Bedürfnissen und Wünschen der Masse der Regierten entfernt. Nur selten genüge ein Erbmonarch den hohen Anforderungen einer Einherrschaft, so Starkeys Argument, und daher sei es besser, die wichtigsten Entscheidungen nicht vom König allein treffen zu lassen, sondern durch den ,commyn counseyl of the reame \& parlyamente assemblyd here in our cuntrey" (S. 68f.), eine Aussage, die er auch mit einem Absetzungsrecht tyrannisch entarteter Herrscher verknüpft.

\section{Der radikalprotestantische, Commonwealth'-Diskurs}

Die englische Reformation, die Abkoppelung der Kirche vom Papsttum unter Henry VIII., war eine ,Reformation von oben', und sie blieb bis zu seinem Tode auch inhaltlich und institutionell, verhältnismäßig konservativ und unentschieden. Gleichwohl eröffneten sich hier Wege für genuine protestantische Gläubigkeit, die nach 1548, zur Zeit des minderjährigen Edward VI., in den Vordergrund trat und auch am Hof in einflußreiche Positionen gelangte. Dieser radikale Protestantismus verstand die englische Reformation als eine bloß begonnene, die zu Ende zu führen sei, und ergriff die Chance der neuen Lage und des eigenen politischen Einflusses zur Formulierung eines nicht bloß kirchlichen, sondern allgemein moralischen, gesellschaftlichen und politischen Reformprogramms. Er konnte dabei anknüpfen an die Tätigkeit Thomas Cromwells, der als de facto erster Minister Henrys VIII. in den 1530er Jahren die Umbruchphase der Kirchenreformation für legislative, politische und administrative Reformen genutzt hatte, die intentional weit über den Kirchenbereich hinauswiesen. Unter starker Aktivierung des Parlaments, das in dieser Zeit eine neue Wirksamkeit und Bedeutung erhielt, demonstrierte er, was eine aktive Politik hinsichtlich der Neuordnung und Regulierung des Gemeinwesens vermöchte. In den Schriften der Radikalreformatoren um 1550 verbindet sich somit ein protestantisches Programm religiöser und moralischer Erneuerung mit Forderungen an die Politik, die moralische Reform durch legislative Reformen gewissermaßen zu begleiten und abzustützen. Und sowohl in den Dokumenten der Cromwellschen Reformzeit, als auch in der Rhetorik der Radikalprotestanten um 1550 spielt der ,Commonwealth'-Begriff eine zentrale Rolle, ${ }^{12}$ wie an vier Autoren exemplarisch gezeigt werden soll.

12 Vgl. Elton 1983, S. 207; 1973; 1979. 
Thomas Becon, Kaplan von Erzbischof Thomas Cranmer, deklamiert in The News out of Heaven, „How slenderly are the poor members of Christ provided for now-adays!“, denn „unmercifulness reigneth among men at this time! "13 Der Reiche hätte seinen Reichtum zu dem Zweck erhalten, für die Armen zu sorgen, und der christliche Glaube fordert, ,that ye walk not only secretly but also openly before God; that is, that ye do not only inwardly in your hearts believe in God, fear and love God, but also that ye outwardly shew forth this your faith, fear and love [...] by external works, that men, seeing your godly conversation, may then glorify your Father which is in heaven" (S. 208). Und in dieser aktivistischen, weltlichen Wendung des Protestantismus "the commodity of the public weal and the health of the country should be sought above all things". Der Reiche, der Starke, der Weise, der Politiker, der Redner, der Gelehrte, der Erfinder, der Landmann, sie alle sollen entsprechend zu ihren Fähigkeiten dem Land dienen (S. 235).

Der wahrhaft christliche Magistrat liebt die Tugend und haßt die Sünde, „tendereth the Commonwealth, and seeketh in all points to be a father among his subjects $[\ldots]^{\text {" }}$ (S. 213f.). Deshalb seien wahre Christen am besten geeignet auch weltliche Macht auszuüben - entgegen der Auffassung jener Strömung im Protestantismus, die eine Vermischung des reinen Glaubens mit weltlichen Dingen durch Separation zu vermeiden trachtete. Diese Strömung verkenne, ,how necessary the office of the public magistrates is for the right institution and prosperous perservation of the common weal. How expedient it [is ...], in matters of controversy, that all things be judged and reconciled according to equity and justice!“ (S. 215). Leider jedoch „,little do many civil magistrates regard the public affairs of the commonalty, so that their coffers may be enriched, and they live in all wealth and pleasure" (S. 253).

Henry Brinklow, ein weiterer Commonwealth-Autor, erklärt es in einer Schrift von 1545 zur Pflicht des Königs, vor dem Hintergrund der Wahrnehmung laufend steigender Grundrenten, „by all godly and polytick meanys to seke the common welth of hys people", und leitet daraus den drastischen Vorschlag ab, die Grundrenten auf das Niveau von vor 40 oder 50 Jahren zwangsweise abzusenken. ${ }^{14}$ Auch er beklagt, daß die Aristokraten, die, anstatt nominelle Grundeigentümer zu sein, selbst agrarkapitalistisch tätig werden, den Landwirten die Existenzmöglichkeiten nehmen und fordert, ihre Viehbestände auf den Eigenbedarf zu beschränken. Explizit wendet sich Brinklow gegen die Einhegungen, denn ,the erth is the poor mannys as wel as the rych" und sei den Reichen als „stewardys" nur leihweise zum Gebrauch überlassen, für den sie daher Rechenschaft geben müssten „unto the Lord for the bestowyng of your ryches" (S.17) ${ }^{15}$. Die im Zuge der Reformation erfolgende Auflösung der Kirchengüter, fordert Brinklow, sollten für die Armenpflege umgewidmet oder dem Gemeindeland zugeschlagen werden. „How can God and mammon agre?"“, fragt er rhetorisch (S. 72), und fordert in seiner Schrift: The Lamentacyon of Christen Agaynst the Cytye of London, die Einziehung oder Umwidmung des Vermögens der Bischöfe, ,so that it maye be disposed to Godes glorye and the commone welthe" (S. 115f.). Hier kritisiert Brinklow auch

13 Becon 1843, hier S. 40. Die im Text folgenden Seitenangaben beziehen sich auf diese Ausgabe.

14 Brinklow 1987, hier S. 10f. Die folgenden Nachweise im Text beziehen sich auf diese Ausgabe.

15 Dieses Motiv findet sich auch bei Robert Crowley (vgl. Crowley 1987, S. 123). 
das reiche städtische Bürgertum, wenn er die große Zahl von Bettlern in London beklagt, vor denen die Reichen der Stadt ihr Herz verschließen. ${ }^{16}$

Adressat Brinklows sind zunächst die Parlamentsmitglieder, die nicht berufen wurden ,for your owne particular and pryvate welth, nor yet for the kynges, in any thing preiudycyal to the comon welth" (S. 17), sondern für eine Reform des Staates im Lichte jenes einzig bedeutsamen ,toch stone, which is Godds word [...]. And where as ye have sought every man his own pryuate or partycular welth, now seke your neyhbors welth as your own" (S. 74). Für Brinklow ist eine radikale Reformation inhaltlich aufs engste mit einem deutlich egalitären Sozialideal und dementsprechenden Gemeinschaftsvorstellungen verknüpft, wie seine manifesten Enteignungs- und Umverteilungsforderungen belegen.

Auch Bischof Hugh Latimer, Leitfigur des radikalen Protestantismus, argumentiert energisch für eine moralische und politische Reform. Im ersten seiner Seven Sermons preached before King Edward the Sixth von 1549 ermahnt er die Reichen, nicht durch übermäßige Anhebung der Grundrenten, indem sie „singular, private wealth and commodity" verfolgen, die Armen auszupressen. Die Folge sei eine Überteuerung und Verknappung von Waren, so daß ,poor men, which live of their labour, cannot with the sweat of their face have a living". Hier sei die Politik gefordert, die eine generelle Wohlfahrtsfunktion hat, die zu gewährleisten hat, daß die Ressourcen des Landes genutzt werden. Und wenn die Größe und Macht des Königs und des Reiches im Bevölkerungsreichtum liegt, dann sind es insbesondere jene Großgrundbesitzer, die in großem Stil Schafzucht betreiben, Einhegungen vornehmen und rücksichtlos die Grundrenten hochschrauben, die dem Reich schaden. Wo vordem nämlich das Land dicht mit wohlhabenden Familien besiedelt gewesen sei, ,there is now but a shepard and his dog". Zwar existierten durchaus gute Gesetze gegen die Einhegungen, die jedoch nicht durchgesetzt werden. ${ }^{17}$

Der radikalprotestantische Pamphletist Robert Crowley schließlich wendet sich, wie alle ,Commonwealth'-Autoren, gegen die Einhegungen und betont zudem die Verpflichtung der Politik, der Stadtverwaltungen, den durch Einhegungen und Inflation aus ihrem Erwerb geworfenen Armen Arbeit zu verschaffen. ${ }^{18}$ Er propagiert eine protestantische Arbeitsethik, die Arbeitsunfähige strikt von Arbeitsunwilligen trennt und von diesen fordert, ihren Lebensunterhalt zu verdienen, was allerdings Arbeitsmöglichkeiten voraussetzt. Die Stadt London kritisiert Crowley, indem er einem normativen Begriff der ,City“ als bürgerschaftlicher Zusammenschluß den Egoismus der Bürger gegenüberstellt (S.11). Im einzelnen kritisiert Crowley Kaufleute, die zu überhöhten Preisen verkaufen, Wucherer, ,Forestallers', die durch monopolistische Praktiken die Preise hochtreiben, sowie bestechliche Magistrate ${ }^{19}$. Den Kirchenzehnten versteht Crowleys als ein ideelles Recht der Armen und fordert, diejenigen zu enteignen und zu bestrafen, die sich daran bereichern (S. 40).

16 Vgl. auch Latimer 1968, Bd. I, S. $63 \mathrm{ff}$.

${ }^{17}$ Latimer 1968, Bd.1, S. $98 \mathrm{ff}$.

$18 \mathrm{Vgl}$. Crowley 1987, S. 122, 10.

19 Siehe auch Latimer, 1968, Bd.1, S. 184ff.; Lever 1870, S. 31 f. 
Die Sozialkritik dieser ,Commonwealth'-Autoren verbindet, bei analytischer und programmatischer Schwäche, eine schrille Tonlage protestantischer Moralität, von der aus die Verelendung von Teilen der Gesellschaft, die soziale Spaltung der Gesellschaft angeprangert werden. Dieser Diskurs, der eine aktivistisch-weltliche Wende im Protestantismus repräsentiert, ist kein Elitendiskurs, denn die Mächtigen und Reichen, auch die bürgerlichen Reichen, Kaufleute, Wucherer, nouveaux riches, werden an das Gemeinwohl gemahnt. Der Diskurs will volkstümlich sein, wenngleich die Autoren als moralische Avantgarde eine erzieherische Distanz zum einfachen Volk wahren. Daraus folgt allerdings auch, daß nicht das Volk, sondern die Eliten, die man scharf kritisiert, zugleich der Adressat der Reformvorschläge sind. Dabei wird auf Grenzziehungen, etwa rechtlicher Art, zwischen ,Privatwohl' und ,Gemeinwohl', kaum Rücksicht genommen: das moralische Gebot des ,Gemeinwohls` erhält fraglose Priorität. In diesem Diskurs wird im Unterschied zum folgenden so gut wie nicht über Institutionen nachgedacht; er erschöpft sich in theologisch-moralischen Motiven, die unmittelbar in politische Forderungen übersetzt werden.

\section{Widerstandstheorie: John Ponet und George Buchanan}

Unter der Herrschaft der katholischen Mary I. Tudor, alsbald ,Bloody Mary` genannt, erlebt das Land im Zuge energischer Rekatholisierung eine scharfe Verfolgung des Protestantismus, dessen Verbindungen mit der Macht gekappt und dessen Wortführer ins Exil gezwungen werden. Die Folge ist eine politische Radikalisierung dieser von der Forschung so genannten ,Marian Exiles' unter Aufnahme kontinentaler Widerstandstheorien. ${ }^{20}$ Vom Ausland aus rufen sie die Engländer zum Sturz der katholischen englischen ,Jezabel ${ }^{\text {' }}$ auf. ${ }^{21}$ Dabei werden zwei Argumentationen miteinander verquickt, die bereits im radikalprotestantischen Reformdiskurs des vorherigen Abschnitts zusammenspielten: eine religiöse, unter Berufung auf die Bibel, und eine moralisch-politische, die das ,Gemeinwohl` anruft. Gemessen am radikalprotestantischen Diskurs der vorhergehenden Phase wird nunmehr jedoch die institutionelle Komponente verstärkt, die im Rahmen eines Widerstandsdiskurses insbesondere auf die Limitierung der Königsmacht zielt.

Als ein Vorläufer dieses Widerstandsdiskurses kann John Bale gelten, der bereits in der Spätphase der Herrschaft Henrys VIII. ins Exil ging und dort eine schwache Version protestantischer Widerstandstheorie formulierte. In seinem Traktat über das JohannesEvangelium beschrieb Bale die ,kings of the earth" als ,more looking for their own preeminence than for the glory of God, the great men more seeking their own pleasures than the commonwealth of the people, the rich men oppressing the poor". Die Obrigkeiten, ,being the mynystrs of god“, heißt es an anderer Stelle, „ought to make no lawes for their private commoditie but for the publyque welthe of ther commons. Neyther ought they to decre any thynge against Gods honor". Tun sie es doch, ,then the rewle of

\footnotetext{
20 Vgl. Walzer 1972.

21 Vgl. Grabes 1991.
} 
the lorde must be orbserved. Necessarye yt ys rather to obey God than manne".22 Der Gemeinwohlgesichtspunkt und der Gehorsam gegen Gott treffen sich hier in einem Widerstandsgedanken, der wohl als Aufforderung zu passivem Ungehorsam zu verstehen ist.

Auch nach John Ponet (Short Treatise of Politicke Power, 1556) ${ }^{23}$ ist legitime politische Herrschaft auf das ,Gesetz Gottes` zu gründen, das sich in der Doppelgestalt eines , law of nature" und als biblische Offenbarung darstellt und für die Menschen verbindlich sei (S. 3f.). Die Bibel jedoch schreibe keine bestimmte Regimeform: Monarchie, Aristokratie oder Demokratie vor und ,left to the discresion of the people to make so many and so few [governors], as they think necessary for the Maintenance of the State". Allerdings habe die Erfahrung die Mischverfassung als die beste erwiesen. Für alle Regime aber gelte die gleiche Zweckbestimmung, ,the maintenance of justice [...] the wealth and benefit of the whole multitude, and not of the Superiour and Governours alone. And when they [die Menschen, das Volk] saw that the Governours abused their authority, they altered the State [...] alwaies preserving and maintaining the authority, albeit they altered and changed the kinde of govemment“. Mit dem Prinzip, daß „Kings, Princes and Govemours have their authority of the people" (S. 49), postuliert Ponet eine Art Volkssouveränität, die wesentlich am Kriterium des allgemeinen Wohls der Masse des Volkes zu aktivieren ist und mit dem ,Gesetz Gottes', von dem letztlich politische Autorität ausgeht, egalisiert wird (S. 5f.). Die Ausübung der Volkssouveränität weist Ponet zunächst den Repräsentativorganen der verschiedenen Länder zu (S. 7). Herrscher in Ländern, die keine derartigen Organe besitzen, sind eher als ,Tyrannen' zu betrachten, denn als ,Könige‘. Allerdings können Könige autokratisch Gesetze und Vorschriften erlassen in „matters indifferent", womit er an die protestantische Adiaphora-Lehre anknüpft. „But in matters not indifferent, but godly and profitably ordayned for the common wealthe, there can they not (for all their autoritie) breake them or dispense with them". Denn die Herrscher seien ,ordained to do good, not to do evil: to take awaie evil, not to increace it: to geve example of well doing, not to be procurers of evil: to procure the wealthe and benefite of their subiectes, and not to worke their hurt or undoing" (S. 13). Die Wohlfahrtsfunktion politischer Herrschaft, am Gemeinwohl orientiert, versteht Ponet so als wesentliches Kriterium ihrer Legitimität.

Ponet grenzt sich dabei nach zwei Seiten ab: gegen die ,Anabaptisten', zeitgenössischer Sammelbegriff für verschiedene protestantische separatistische Sekten, und gegen die ,Papisten“. Während die einen unter Berufung auf eine falsche, christian liberty alle politische Autorität ablehnen, sind die anderen allzu autoritätsgläubig und liefern das Volk und das Gemeinwohl der Willkür der Herrschenden aus (S. 22). Dagegen hält er, daß jenen Herrschern, deren Befehle im Widerspruch zum Wort Gottes oder zum Gemeinwohl stehen, nicht zu gehorchen, sondern Widerstand zu leisten sei, denn „men ought to have more respect to their Countrey than to their Prince: to the Commonwealth, than to any one person. [...] Next unto God, men ought to love their Countrey, and the whole Commonwealth, before any member of it". Das Ganze, das Gemeinwesen, steht über dem Einzelnen, dem Herrscher. Reproduziert Ponet hier die herkömmli-

22 Bales zitiert nach Kelley 1988, S. 329, 64f.

${ }^{23}$ Ponet 1639. Die im Text folgenden Seitenangaben beziehen sich auf diese Schrift. 
che organologische Metapher des Gemeinwesens als ,body politic', so weist er doch die Auffassung zurück, das Gemeinwesen erhalte gleichsam erst im Herrscher Gestalt und Wirklichkeit. Das ,Gemeinwesen' wird als in sich lebensfähig begriffen, während politische Herrschaft eine bloße abgeleitete und subsumierte Funktion ist. Und daraus folgt, daß „Emperours, Kings, Princes, and other Governours' abusing their office, [may] be deposed, and removed out of their places and offices, by the body or state of the Realm or Commonwealth“, denn „God [...] will [...], that the Magistrates doings be called to account and reckoning, and their vices corrected and punished by the body of the whole Congregation or Commonwealth" (S. 49).

Bei dem schottischen Humanisten George Buchanan tritt die Fundierung der Legitimität von Widerstand auf die Bibel stärker in den Hintergrund. Er lieferte die wichtigsten ideologischen Begründungen für die Absetzung der schottischen Königin Mary Stuart 1567. Vom schottischen Parlament zum Erzieher des minderjährigen James VI. ernannt, verfasste Buchanan etwa 1568 den politischen Dialog De Jure Regni apud Scotos, der 1578 publiziert wurde. ${ }^{24}$ Argumente, die unmittelbar die Absetzung der Königin legitimieren, werden hier auf eine allgemeine Ebene gehoben. Antike Traditionen des Tyrannenmordes und bürgerhumanistische Einflüsse gehen darin mit Berufungen auf die Bibel eine eloquente Verbindung ein. Wesentliches Kriterium legitimen Widerstandes gegen ungerechte Herrschaft ist auch hier das Gemeinwohl.

Buchanan geht vom aristotelischen Bild des Menschen als ,zoon politikon' aus. Allerdings muß es, politische Autorität geben, weil die Menschen von sich aus keine Einigkeit zu bewahren wissen. Grundlegend wird die politische Autorität vom Volk verliehen, und das Volk ist frei darin, wem es sie verleiht. Durch lange, schmerzhafte Erfahrung haben die Völker gelernt, ihre Freiheit eher den Gesetzen anzuvertrauen, als ihren Königen, denn während diese leicht den Pfad der Gerechtigkeit verlassen, ist das Recht taub gegenüber Einflüsterungen und Drohungen und "pursues the one, unbroken course" (S. 57). Da jedoch nicht das gesamte Regierungshandeln durch Gesetze regulierbar ist, bleibt dem Fürsten notwendig ein Entscheidungsspielraum, der durch verbindliche Beratungsgremien und durch die Abspaltung spezieller Kompetenzen, besonders im Bereich der Rechtsauslegung und -anwendung, zu limitieren ist (S. 64f).

Wer gibt die Gesetze? Generell gilt, daß das Volk die Grenzen fürstlicher Autorität setzt, und es kann und sollte sich vorbehalten, an der Gesetzgebung mitzuwirken. In Schottland nimmt das Parlament diese Funktion wahr. Dabei weist Buchanan die üblichen Einwände gegen die Demokratie: die Unbeständigkeit und Beeinflußbarkeit von Volksversammlungen, unter Berufung auf das aristotelische Argument zurück, daß, wenn die Individuen einer demokratischen Versammlung einseitig in der Wahrnehmung einzelner Aspekte eines Regelungsproblems sind, sie zusammengenommen doch größere Einsicht und Weisheit versammeln, als irgend ein Individuum (S. 71f.).

Nach dieser Exposition guter Herrschaft und ihrer Bedingungen wirft Buchanan das Problem der, ,Tyrannis‘ auf. Er bestimmt den ,König' in Abgrenzung zum ,Tyrannen“ durch die Kriterien der Zustimmung der Regierten, ihres Rechtsstatus als Freie und durch die Zweckgebundenheit der Regierung an das Gemeinwohl (S. 92). Diejenigen daher, die „openly rule for their own selfish advantage and not for that of their country,

\footnotetext{
${ }^{24}$ Buchanan 1949. Die im Text folgenden Seitenangaben beziehen sich auf diese Schrift.
} 
and who do not consider the public interest, but only their own pleasures, who depend upon the weakness of the people for the security of their authority and who regard the kingly office not as a trust committed by God, but rather as booty turned over to them, are not united with the rest of us by any bond of common citizenship or of humanity; but ought rather to be counted the most dangerous enemies of God and of all mankind" (S. 93). Dieser tyrannisch entartete Herrscher - ein Argument, das John Locke später aufnehmen wird - stellt sich eo ipso außerhalb der Gesetze und verwirkt seinen Anspruch, als Mitglied einer politischen Gesellschaft behandelt zu werden. Zwischen dem monarchischen Amt und der Person des Monarchen sei daher zu unterscheiden.

Den Einwand, daß, wie gut begründet immer die Limitierung monarchischer Herrschaft sei, der Versuch, sie praktisch gegen die Krone zur Geltung zu bringen, notwendig zu Unruhen führen müsse, behandelt Buchanan als ,,appealing to tyranny to sanction tyranny“, nämlich „,the tyranny of custom“, denn nach diesem Argument könnte man eine Tyrannis niemals abschütteln und würde auf den Status der Völker Asiens absinken, die niemals eine freie Regierung kannten (S. 110f). Und wenn man die Herrschaft eines Tyrannen quietistisch als Strafe Gottes ansieht, was verbreiteter Überzeugung entsprach, kann mit gleichem Recht auch der Tyrannenmord als eine gottgewollte Tat legitimiert werden, denn es sei Gottes Gebot, ,Übeltäter' zu bestrafen. Wer aber soll den König zur Rechenschaft ziehen? Wenn der König unter dem Gesetz steht, muß die Autorität, die die Gesetze gibt, auch für ihre Durchsetzung Sorge tragen. Und da diese ursprüngliche Quelle aller Gesetzgebung nur das Volk sein kann, ist das Volk selbst aufgefordert, einen schlechten Herrscher zur Rechenschaft zu ziehen (S. 130). Denn so wie das Mittel in einem untergeordneten Verhältnis zum Zweck steht, dienen die Gesetze dem Wohle des Volkes, das letztlich nur selbst über sein Wohl und die GesetzmäBigkeit einer Herrschaft entscheiden kann.

Welche pragmatischen Bedingungen existieren für die Selbstbehauptung des Volkes gegenüber einem Tyrannen? Zunächst: Die Tyrannis begünstigt nur wenige, während sie vielen schadet; und diese wenigen Begünstigten werden sich nicht einmal stark an den Tyrannen binden, denn es sind Opportunisten, die sich im Falle von Gefahr abwenden werden. Auf der anderen Seite, so Buchanan, wird es immer Bürger geben, für die Rechtlichkeit, die Integrität der Bürgergesellschaft und Ehre hohe Werte sind, für die es sich lohnt, hohe Risiken einzugehen, für die der Ruhm zukünftiger Zeiten Bedeutung hat. Hier wird an den antiken Tugenddiskurs des Tyrannenmordes angeknüpft. Bevor jedoch an aktiven Widerstand zu denken ist, muß auf die Justiz als Wahrerin der Gerechtigkeit auch gegenüber dem König rekurriert werden. Als Wahrer des Rechts haben die Richter eine Funktion, die nicht unter, sondern über der Krone steht (S. 136), denn nicht Herkunft, Rang und Status des Richters als Person sind maßgebend, sondern daß sie Repräsentanten des Rechts sind (S. 137f.). Falls sich jedoch der Tyrann gerichtlicher Verantwortung entzieht, ist auch bewaffneter Widerstand legitim, denn Konflikte zwischen den Nationen und zwischen dem Volk und seinen Herrschern sind durch Waffengewalt zu entscheiden, ,when the law cannot settle the issue“ (S. 142). In diesem Fall ist der Herrschaftsvertrag zwischen dem Fürsten und dem Volk als aufgekündigt zu betrachten, und der Krieg gegen einen Tyrannen ,is the most just [war] of all" (S. 143). In diesem Krieg mag es auch dem Einzelnen gestattet, ja geradezu geboten sein, den 
Tyrannen zu töten, wenn er die Gelegenheit hat. Allerdings warnt Buchanan auch vor einer leichtsinnigen Erhebung: Das Recht des Widerstandes legitimiert nicht seine Wahrnehmung unabhängig von Zeit, Ort und Bedingungen.

Übergreifende Bedeutung hat Buchanans Anliegen, die tradierte Unterscheidung des gerechten Herrschers vom Tyrannen anhand des Kriteriums des Gemeinwohls institutionell operationalisierbar zu machen, wobei die deutliche Abhebung des Amtes von der Person des Monarchen hervorzuheben ist, die in Wendung gegen die tradierte Sakralität des Monarchen auf ein Amtsverständnis politischer Funktionalität verweist. Ein derart ,modernes' Amtsverständnis ruht auf der - wenngleich vage bleibenden - Souveränität des Volkes, nach der letztlich nur das Volk selbst (respektive seine Repräsentanten) verbindlich über sein politisches Wohl entscheiden kann.

\section{V. ,Country` versus, Court`: Konflikte um Souveränität}

Die Absetzung der schottischen Königin fand ihre Parallele in England 1649 in der Verurteilung und Hinrichtung Charles I. Dem war ein langjähriger Prozess konflikthafter Zuspitzung des Streites zwischen Krone und Parlament über die respektiven politischen Kompetenzen vorausgegangen. Während sich die Stuart-Könige - vor allem James I., in deutlicher Wendung gegen die Theorien seines Lehrers Buchanan ${ }^{25}-$, auf die Tradition des ,Divine Right of Monarchy' beriefen, die dem König ein souveränes Letztentscheidungsrecht in allen Angelegenheiten gewährt, stützte sich das Parlament auf die Tradition repräsentativer Limitierung der Krone, die inhaltlich sukzessive ausgeweitet wird - und damit bricht Fortescues Dominium politicum et regale auseinander. Natürlich wurde hier über das Gemeinwohl gestritten, aber sehr früh schon verlagerte sich der Akzent auf die Frage der Definitionskompetenz des Gemeinwohls; die substantielle Frage nach dem Gemeinwohl wird überlagert von der Verfahrensfrage politischer Souveränität. Die von Jean Bodin vor dem Hintergrund der Religionskriege in Frankreich ausgearbeitete moderne Souveränitätskonzeption implizierte bereits die Neutralisierung emphatischer Gemeinwohlideen solange Frieden, Sicherheit und Schutz des Eigentums gewährleistet sind, und in diese Richtung bewegte sich auch die politische Theorie Thomas Hobbes, der eine naturrechtlich-rationalistische Fundierung moderner Souveränität vornahm, die gegenüber der Frage der institutionellen Verortung der Souveränität gleichgültig bleibt, solange der Streit über das Gemeinwohl aus der Gesellschaft herausgenommen und durch Monopolisierung beim Souverän befriedet wird. Das war in den späten 1630 er Jahren, als Hobbes erstmals seine Theorie ausarbeitete, ${ }^{26}$ eine royalistische These, denn die Krone reklamierte diese souveräne Definitionskompetenz und suchte die gesellschaftliche Debatte über das Gemeinwohl zu unterdrücken, während das Parlament mit der Verletzung grundlegender Rechte und des Gemeinwohls argumentierte und die öffentliche Meinung in seinem Sinne zu mobilisieren suchte. Insoweit wird der Streit über das Gemeinwohl und seine Definitionsmacht auch zu einem über die Öffnung respektive Schließung politischer Diskursräume.

\footnotetext{
${ }^{25}$ James VI and I 1994.
}

${ }^{26}$ Hobbes 1999. 
Komponente der Rhetorik parlamentarischer Opposition war die Denunziation des Hofes als eines Zentrums selbstinteressierter Korruption, während sie sich als Anwalt des Landes und der Masse seiner Einwohner stilisierte: ,Country ${ }^{*}$ versus ,Court ${ }^{\star}$. Als charakteristisch können Verse gelten, in denen sich der Unterhausabgeordnete Sir Benjamin Rudyerd 1632 als Ideal eines unabhängigen Abgeordneten stilisierte, „who choose rather to be Good / Than Great or Riche; whoe so well understood / Yet practiz'd not, Court Artes: for all his Frends / Found that he lov'd them for Themselves, not Ends. /

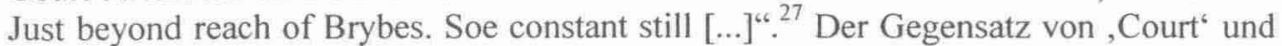
,Country' liegt auch einem 1628 posthum publizierten Dialog des populären Humanisten und Seehelden Sir Walter Raleigh zugrunde. ${ }^{28}$ Darin sucht der Friedensrichter ehrenamtliche Funktion führende Grundbesitzer in den ,Counties` - dem Repräsentanten des Hofes klarzumachen, daß die Krone in England ohne und gegen den im Parlament zum Ausdruck kommenden Willen des Landes nicht erfolgreich regieren kann.

Die 1620 er Jahre vor allem sahen eine wachsende Entfremdung zwischen der Krone und der öffentlichen Meinung im Kontext der - katastrophal fehlschlagenden - Intervention Englands im dreißigjährigen Krieg. Während James I. nach allgemeinem Empfinden allzu zögerlich reagierte und lange an der Hoffnung festhielt, seinem Schwiegersohn, Friedrich I. von der Pfalz, das durch Habsburger Truppen besetzte Kurfürstentum auf dem Verhandlungswege zurückzugewinnen, verfolgte Charles I für einige Jahre eine offensive kontinentale Kriegspolitik, die aber im Gegensatz stand zu dem vom Parlament geforderten Seekrieg gegen Spanien, von dem es sich lukrative Prisen und die Ausdehnung englischer Handelsräume versprach. Ergebnis seiner Politik war die gravierende Verschuldung der Krone bei minimalen militärischen Resultaten und ein drohendes parlamentarisches ,Impeachment ' gegen seinen Günstling, den Duke of Buckingham, den die Öffentlichkeit für die Fehlschläge verantwortlich machte. Nur die vorzeitige Auflösung des Parlaments bewahrte Buckingham vor parlamentarischer Verurteilung. Die ,Commonwealth'-Rhetorik nimmt in diesem Kontext die Bedeutung an, den Willen des Landes gegen die Krone zu artikulieren und die ,evil counsells ‘ anzuprangern. Und das Neue der Situation besteht darin, daß diese Kontroverse über Außenund Militärpolitik, die staatsrechtlich eindeutig in die ausschließliche Kompetenz der Kronprärogative fiel, nicht auf die geschlossenen Räume von Whitehall und Westminster-Palace beschränkt blieb, sondern eine lebhafte Publizistik hervorrief, in der sich militanter Protestantismus und anti-spanische Seeherrschaftsziele zu einem aggressiven Patriotismus verbinden, der innerhalb und außerhalb des Parlaments artikuliert wird. Unter dem Einfluß dieser Propaganda kommt es $1628 \mathrm{zu}$ einem erfolgreichen Attentat auf Buckingham, das insgeheim sicher von nicht wenigen Beobachtern unter dem $\mathrm{Mu}$ ster des ,Tyrannenmordes' betrachtet wurde.

Thomas Scott, ein schottischer Prediger, publizierte in diesen Jahren eine Vielzahl politischer Pamphlete, in denen er das Recht beansprucht, ja geradezu als patriotische Pflicht bezeichnet, sich auch als einfacher Bürger zum Krieg als Schicksalsfrage der Nation ein Urteil zu bilden und zu äußern, um den Einfluß der schlechten Ratgeber auf

27 Griffiths 1998, Nr. 57.

28 Raleigh 1628. 
den König zu brechen. ${ }^{29}$ Grundsätzlich ist Scott ein Anhänger des Seekrieges gegen Spanien. ${ }^{30}$ Aber er kritisiert auch die ,Bargaining'-Taktik des Parlaments, das sich angewöhnt hatte, Steuerbewilligungen von Zugeständnissen des Königs hinsichtlich verschiedener innenpolitischer ,Grievances' abhängig zu machen - eine Taktik, die einer energischen Kriegführung entgegenstand. Diese ,Grievances“, so Scott, „for the most part do concern but some of them one member, and some another of the Commonwealth, and may have more time to deliberate on", während ,the present necessitie of defending of the Kingdom is the publick grievance of the whole Commonwealth $[. . .]^{\text {". }}$. Der Krieg gegen die Mächte der Gegenreformation „concerns the whole Land, we are all ingaged in it for ourselves, and for our posteritie, and it cannot admit of any delay, for it is our own cause as well as the King's". 31

Unter anderem in Reaktion auf ein Pamphlet Scotts hatte noch in der frühen Phase der Kriegskontroverse James I. eine Proklamation gegen die öffentliche Diskussion der AuBen- und Kriegspolitik erlassen. Darin kritisiert er die ,greater opennesse, and libertie of discourse, even concerning matters of State (which are no Themes, or subjects fit for vulgar persons, or common meetings) than in former times, used or permitted". Parallel ermahnte Francis Bacon als Lordkanzler das Parlament zur Zurückhaltung, denn ,advice is to be given with distinction. [...] in those things that are Arcana Imperii, and reserved points of sovereignty, as making of war and peace, and the like, there they are to apply their advice to that which shall be communicated unto them by the King, without pressing further within the veil, or reaching forth to the forbidden fruit of knowledge ${ }^{632}$. Die Entstehung einer politischen Öffentlichkeit, das zeigt die Geschichte, war jedoch nicht zu stoppen: im Parlament wurden immer öfter ,Fensterreden" gehalten, die eventuell schon gedruckt waren, Massenpetitionen wurden organisiert und schließlich, in der letzten Phase vor Ausbruch des Bürgerkrieges, auch Massendemonstrationen, selbst militante, die etwa die Bischöfe an der Teilnahme an Sitzungen des Oberhauses hindern sollten. Der Hof verlor sukzessive die Kontrolle über die politische Öffentlichkeit. Mit Ausbruch des Bürgerkrieges bricht die Zensur zusammen und Bemühungen der presbyterianischen Parlamentsmehrheit, eine neue Zensur zu etablieren, bleiben ineffektiv. Erst mit der Konsolidierung des Cromwellschen Regimes und nach der Restauration erlangt das politische Machtzentrum wieder eine gewisse Kontrolle der Diskurse. Die Idee, gleichwohl, die Erörterung wesentlicher politischer Fragen im Kronrat zu monopolisieren, ist obsolet geworden: zukünftig müssen die Regierenden mit einer politischen Nation rechnen, die selbständig über Fragen des Gemeinwohls urteilt. Mit dieser Öffnung der Diskursräume wird das Gemeinwohl als diskursvermittelte Perzeptivität dramatisch dynamisiert.

29 Siehe Peltonen 1995, Kap. 5.

${ }^{30}$ Vgl. Scott 1973: Vox Dei, Vorwort.

31 A Speech made in the Lower House of Parliament, by Sir Edward Cicell, Colonel, 1624, Scott 1973, S. 5.

32 Vgl. Bacon 1994, S. 172. 
VI. ,Salus Populi suprema Lex“

In den 1630er Jahren, zur Zeit der parlamentslosen ,Personal Rule' Charles' I, reklamierte die Krone, von der Mehrheit der Richter unterstützt, im Zusammenhang mit dem ,Ship Money' und dem Prozess über inhaftierte prominente Verweigerer, das Definitionsrecht über Ausnahmesituationen, die jenseits der normalen Rechtskontrolle lagen. Das ,Ship Money“ wurde, um diese Abgabe juristisch haltbar zu machen, mit einer äußeren Bedrohungslage begründet, über deren Existenz oder Nicht-Existenz ausschließlich die Krone zu befinden habe, und die Inhaftierung der Verweigerer, ohne Begründung und sine die, wurde mit ,Matters of State' begründet, deren Offenlegung als Arcana Imperii von den Gerichten nicht erzwungen werden könne. In der Sprache der Krone verknüpfte sich die traditionelle, aber juristisch schlecht definierte Idee der Kronprärogative mit der Denkweise und Rhetorik des kontinentalen Diskurses der Ragione di Stato. Diese Diskursstrategie löste jedoch Lerneffekte auf Seiten des Parlaments aus und schlug in der Phase intensivierter Legitimationskonkurrenz zwischen Krone und Parlament, als der Bürgerkrieg unausweichlich zu werden schien, auf die Krone zurück, denn nunmehr sind es Parlamentspublizisten, die das Ausnahmerecht der Salus Populi suprema Lex (Cicero) heranziehen, um eine parlamentarische Regierung ohne und gegen den König zu legitimieren. Die bisherige Legitimationsstrategie der Opposition, sich auf rechtsbasierte Institutionen zur Limitierung der Königsherrschaft zu berufen, wird damit überschritten, indem in der Ausnahmesituation elementare ,Gemeinwohl'-Forderungen vital werden, die eine formal austarierte Institutionenbalance sprengen; gleichwohl bleibt diese Überschreitung, das soll gezeigt werden, an Rechtsdiskurse angebunden, die substanzialistisch gewendet werden.

Henry Parker hatte 1640 die Urteile im ,Ship Money'-Prozeß kritisiert, wichtiger sind jedoch seine Observations upon some of his Majesties late Answers and Expresses von 1642, die auf die ,Answer to the Nineteen Propositions of Parliament' des Königs reagieren. ${ }^{33}$ Die wenig gradlinige Argumentation Parkers basiert zunächst auf dem Postulat, daß „Power is orginally inherent in the people“, und daß der König, nach dem Satz des römischen Rechts, sei singulis major sed universis minor. Dem König schreibt er daher lediglich ein ,interest in the Crowne [...] in part condinionate and fiduciary", als „Trust“, zu (S.167ff.). Denn im Laufe der Zivilisation sei es den Völkern gelungen, Limitierungen des Souveräns zu entwickeln - Recht und Parlamente -, die die Freiheit sichern, ohne in Anarchie auszuarten (S. 181). Darüber hinaus aber beruft sich Parker auch auf die Salus populi als „Paramount Law“, das in der aktuellen Situation des Auseinanderfallens der obersten Legislativorgane bei akuter Bedrohung durch die aufständischen Iren virulent wird und ein Selbstverteidigungsrecht des Volkes aktualisiert, wenn der König seiner Pflicht, das Land zu verteidigen, nicht nachkommt. Damit zielt Parker vor allem auf die Unentschiedenen, denen er das Parlament als Schutz- und Ordnungsmacht gegenüber einem pflichtvergessenen König darstellt.

Wenn sich der König auf sein Gewissen beruft, indem er dem Parlament Widerstand leistet, dann handelt es sich lediglich um „meere private opinion“, während das Parla-

33 Vgl. Parker 1999; Parker 1934; Answer, in: Wootton 1986. 
ment den Rat der Nation repräsentiert (S.191f.). Das Parlament sei ,vertually the whole kingdome it selfe" und ,the supreame judicature, as well in matters of State as matters of Law“, „the great Councell of the Kingdome, as well as of the King“ (S. 194). Das Parlament bildet das höchste Beratungsorgan des Landes, ,and when it is unjustly rejected, by a King seduced, and abused by private flatterers, to the danger of the Commonwealth, it assumes a right to judge of that danger, and to prevent it". Die Souveränität wird von Parker dem Parlament in dem Satz vindiziert, ,,every State [habe] an Arbitrary power over it self [...]. If the State intrusts this to one man, or few, there may be danger in it; but the Parliament is neither one, nor few, it is indeed the State it self" (S. 199f.). Insofern es daher keine höhere Entscheidungsinstanz im Streit zwischen Krone und Parlament gibt und geben kann, gebührt dem Parlament der Gehorsam.

Im gleichen Jahr sucht der Presbyterianer Charles Herle in einer Polemik gegen den Royalisten Henry Ferne ${ }^{34}$ den Supermat des Parlaments zu begründen, indem er von der These ausgeht, England sei eine „Coordinative, and mixt Monarchy", deren drei oberste Gewalten: König, Unterhaus und Oberhaus gleichberechtigt sind (S. 228). Der Supremat der beiden Häuser des Parlaments wird dann aus zwei Überlegungen abgeleitet: Erstens vereinen zwei von drei gleichberechtigten obersten Gewalten eine größere Legitimation auf sich als die dritte im Gegensatz zu ihnen, und zweitens, was für die konkrete Situation und den Beweiszweck Herles von größter Bedeutung ist, sind diese drei Gewalten in ihren Kompetenzen nicht autonom definiert, sondern stehen in einem Substitutionsverhältnis. Eine mögliche Blockade wird überwunden, indem die Funktionen eines der drei Organe, das versagt, substitutiv durch die anderen erfüllt werden können. Daraus leitet Herle das Recht der beiden Häuser des Parlaments ab, auch ohne und gegen den König verbindliche Letztentscheidungen zu treffen.

Den Beweis für die Gleichberechtigung der drei obersten Staatsorgane sieht er in ihrer notwendigen Mitwirkung bei der Gesetzgebung und Gesetzesauslegung, ,the two highest acts of Supreame power" (S. 253). Die Substitution, d.h. die Ausschaltung des allgemein anerkannten königlichen Vetos, war der schwierigere Beweis, denn natürlich ist ein Veto, das überdeterminiert werden kann, nicht eigentlich mehr ein Veto. Dieses Argument kann Herle nur an Notstandssituationen koppeln, während aber ja gerade die Definition des Notstandes und die richtige Antwort darauf umstritten waren. Er gerät also in einen gedanklichen Zirkel und zieht sich auf eine Argumentationslinie zurück, die nicht mehr die volle Souveränität für das Parlament reklamiert und im übrigen der offiziellen Argumentation des Parlaments selbst entspricht. Notstandsentscheidungen des Parlaments seien ,not an Act of Parliament, or Law; 'tis but an occasionall supply of this coordination of the government (in case of one part's refusall) least the whole should ruine, and to continue but untill a Law may be had" (S. 235). Damit wird die vom Parlament stets beschworene ,Rule of Law' durch eine ,Rule of parliamentary Ordinance' ersetzen. Unterstützend greift Herle daher auf die bereits von Parker formulierte These der, Virtual Representation' des Reiches im Parlament, auch ohne den König, zurück (S. 245).

${ }^{34}$ Herle, 1999. Die folgenden Seitenangaben im Text beziehen sich auf diese Schrift. 
Etwas anders argumentiert der anonyme Verfasser des Traktats Touching the Fundamentall Lawes, or Politique Constitution of this Kingdome vom Februar $1643 .{ }^{35} \mathrm{Er}$ setzt ein mit der Idee einer ungeschriebenen Verfassung, die nicht als Vereinbarung zwischen Krone und Volk zu verstehen sei, sondern als eine Sammlung von Grundsätzen, durch die sich die Gemeinschaft eine politische Ordnung gibt und die letztlich auf das Prinzip der ,Salus populi“ reduzierbar sind. „Fundamentall Laws are not (or at least need not be) any written agreement like Meare-stones between King and People", und der König, dessen ,juridicall and lawfull authority" auf den Gesetzen des Landes beruht (S. 265), ist als politische Figur „a part (not party) in those Laws“. Ihm ist die Regierung als ,Trust ${ }^{\star}$ anvertraut, unter der Kontrolle des Parlaments. Die Verfassung „is a Law held forth with more evidence, and written in the very heart of the Republique, farre firmlier than can be by pen and paper" (S. 264), denn die Idee von Grundgesetzen, die nur als verschriftete Gültigkeit haben sollen, würde alles ins Chaos stürzen, weil dann der König vom Parlament, und das Parlament vom König respektive den Aufweis ihrer schriftlichen Legitimierung fordern würden, was keine von beiden Seiten leisten könnte. Damit ist die Sackgasse beschrieben, in die der Verfassungskonflikt zwischen Krone und Parlament geführt hatte. Um aus ihr herauszukommen müsse von einem impliziten Vorverständnis der Verfassung ausgegangen werden, die Parlament und Krone an jenes oberste ,Gesetz bindet, das der Verfassung als Idee der Selbstregulation des Gemeinwesens zugrundeliegt: Salus populi, oder genauer, „An honourable and safe Regiment of the Common-wealth" (S. 265). Diese ungeschriebene Verfassung kann inhaltlich nur allgemein definiert werden, um jenen Freiraum zu gewinnen, der gestattet, das positive Recht, geschriebenes und ungeschriebenes, altes und neues, sowie das Handeln der Verfassungsorgane jederzeit im Lichte der Verfassungsgrundsätze einer Kontrolle und Überprüfung zu unterziehen.

Die wesentliche Frage bleibt, wer über die ,Salus populi' entscheidet, und an dieser Stelle wird die politische Tendenz des Verfassers greifbar, der die Idee einer ungeschriebenen Verfassung benutzt, um das Parlament aus den Schranken des positiven Rechts zu emanzipieren. Wenn es, durch das Versagen des Königs gezwungen, seine traditionellen staatsrechtlichen Kompetenzen überschreitet, dann erscheint das insoweit als legitim, als es für die Sicherung der ,Salus populi' notwendig ist. Die Salus populi als Grundgesetz entzieht sich verbindlicher Fixierung und benötigt daher eine Agentur, das Parlament, die dieses Lebensprinzip der Verfassungsordnung organhaft verkörpert. So wie es kein Gesetz oberhalb der Salus populi geben kann, kann es daher kein Organ und kein geschriebenes Gesetz oberhalb des Parlaments geben. Diese , ungeschriebene Verfassung ' wird vital vor allem unter Notstandsgesichtspunkten, die zur Sprengung des positiven Rechts zwingen. Die politisch motivierte petitio principii liegt in der Zuschreibung der Definitionsmacht der ,Salus populi“ zum Parlament, verstanden als „representatively the Publike, intrusted for it, which is like to partake and share with the Publike, being but so many private men put into authority pro tempore, by common consent, for common good" (S. 270). Virtuell das Volk, kann nur das Parlament über das Wohl des Volkes entscheiden. Die Eigentümlichkeit dieses Traktates liegt darin, die legalistische Rhetorik des Parlaments durch Rückgriff auf das Motiv der ,Salus populi“

35 Anonymus 1999. Die folgenden Seitenangaben im Text beziehen sich auf diese Schrift. 
zu hintergehen, also nicht nur das Parlament als Souverän zu rekonstruieren, sondern auch als durch positives Recht nicht gebunden und nicht bindbar darzustellen. Insofern bezweckt dieser Rückgang auf eine gegenüber dem positiven Recht höherstufige ,Verfassung' nicht, worauf eine Verfassung im modernen Verständnis zielt: die Rechtsbindung der Staatsorgane, sondern im Gegenteil die Freisetzung des Parlaments aus positivrechtlichen Bindungen.

\section{Schluß}

Ausgehend von der These der Bedingtheit der ,Gemeinwohl'-Semantik durch die Gefährdung des ,Gemeinwohl'-Konsenses wurde versucht, bedeutsame Konjukturen der ,Gemeinwohl'-Semantik in England in dem untersuchten historischen Zeitraum in ihren polemischen Kontexten zu rekonstruieren. Dabei wurde abgestellt auf das Spannungsverhältnis zwischen substantiellen Begründungen einerseits und formal institutionalisierter Definitionsmacht des ,Gemeinwohls“ andererseits. Letzteres dient pragmatisch der Entkrampfung, Entschärfung substantieller ,Gemeinwohl'-Konflikte, und die historische Tendenz weist deutlich in Richtung inklusiver Konsensbeschaffungs- und Legitimationsformen. Gleichwohl wurde sichtbar, dass unterhalb dieser Verschiebung in formale Legitimationsformen substantielle ,Gemeinwohl'-Diskurse fortwirken, eventuell in Widerspruch zu den Verfahren treten und sie im Extremfall fundamentalistischer Aufladung sprengen. Die systemische ,Legitimation durch Verfahren' (Luhmann 1989) bleibt, so scheint es, auf substantielle Konsensbestände über das ,allgemeine Wohl angewiesen. Die Befriedung des Konflikts zwischen dem ,Gemeinwohl' als offener und offen zu haltender Diskurs und der institutionellen Fixierung der Definitionsmacht über das ,Gemeinwohl' kann nicht ein für allemal, sondern nur pro tempore gelingen, indem von Zeit zu Zeit Konsens darüber erzielt wird, welche Ebenen des ,Gemeinwohls‘ diskursiv geöffnet oder geschlossen und welche welchen Entscheidungsverfahren subsumiert werden.

\section{Literatur}

Anonymus (1999), Touching the Fundamentall Lawes, or Politique Constitution of this Kingdome, 1643, in: J. L. Malcolm (Hg.), The Struggle for Sovereignty. Seventeenth-Century English Political Tracts, 2 Bde., Indianapolis, Bd.1, S. 261-79.

Bacon, Fr. (1994 ${ }^{2}$ ), The Works of Francis Bacon, hg. v. J. Spedding et al., 14 Bde., London, 18571874, Reprint, Stuttgart/Bad Cannstatt, Bd.14.

Bale, J. (1849), Select Works of John Bale, Bishop of Ossory, The Parker Society, hg. v. Rev. H. Christmas, Cambridge.

Becon, Th. (1843), The Early Works of Thomas Becon, hg. v. J. Ayre, The Parker Society, Cambridge.

Brinklow, H. (1987), Henry Brinklows Complaynt of Roderick Mors, and The Lamentacyon of a Christian agaynst the Cyty of London, made by Roderigo Mors, hg. v. J. Meadows Cowper, Early English Text Society; 1874, Reprint, New York. 
Buchanan, G. (1949), The Powers of the Crown in Scotland, being a Translation, with Notes and an Introductory Essay, of ,De Jure Regni apud Scotos`, by Charles F. Arrowood, Austin.

Burns, J. H. (1993), George Buchanan and the anti-monarchomachs, in: Political Discourse in Early Modern Britain, hg. v. N. Phillipson/Q. Skinner Cambridge, S. 3-22.

Crowley, R. (1987), The Select Works of Robert Crowley, hg. v. J. Meadows Cowper, Early English Text Society, 1872, Reprint, Millwood (New York).

Elton, G. H. (1990), Humanism in England, in: The Impact of Humanism on Western Europe, hg. von A. Goodman/A. MacKay, London/New York, S. 259-78.

Elton, G. H. (1973), Reform and Renewal. Thomas Cromwell and the Common Weal, Cambridge.

Elton, G. H. (1979), Reform and the commonwealth-men of Edward VI's reign, in: The English Commonwealth. 1547-1640. Essays in Politics and Society, presented to J. Hurstfield, hg. v. P. Clarke et al., Leicester, S. 23-38.

Elton, G. H. (1983), England unter den Tudors, München.

Fortescue, Sir John (1997), On the Laws and Governance of England (ca. 1460-72), hg. v. Sh. Lockwood, Cambridge.

Grabes, H. (1991), England oder die Königin? Öffentlicher Meinungsstreit und nationale Identität unter Mary Tudor, in: Nationale und kulturelle Identität. Studien zur Entwicklung des kollektiven Bewußtseins in der Neuzeit, hg. v. B. Giesen, Frankfurt/M., S. 121-68.

Griffiths, A. (1998) (with collaboration of R. A. Gerard), The Print in Stuart Britain, 1603-1689, London.

Herle, Ch. (1999), A Fuller Answer to a Treatise Written by Doctor Ferne, Entituled, The Resolving of Conscience, in: J. L. Malcolm (Hg.), The Struggle for Sovereignty. Seventeenth-Century English Political Tracts, Bd.1, S. 223-260.

Hobbes, Th. (1999), The Elements of Law, Natural and Politic (1640), with Three Lives, hg. v. J. C. A. Gaskin, Oxford.

Holinshed, R., et al. (1808), Holinshed's Chronicles of England, Scotland and Ireland, 6 Bde., London.

James VI and I (1994), Political Writings, hg. v. Joh. P. Sommerville, Cambridge.

Jones, H. (1998), Master Tully. Cicero in Tudor England, Nieuwkoop.

Kelley, D. R. (1988), Ideas of Resistance before Elizabeth, in: The Historical renaissance. New Essays on Tudor and Stuart Literature and Culture, hg. v. H. Dubrow/R. Strier, Chicago/London, S. 48-76.

Kurath, H. (Hg., 1959): Middle English Dictionary, Ann Arbor.

Larkin, J. F./P. L. Hughes (Hg., 1973), Stuart Royal Proclamations, Bd.1: Royal Proclamations of King James I, 1603-1625, Oxford.

Latimer, H. (1968), The Works of Hugh Latimer, The Parker Society, hg. v. G. E. Corrie, 2 Bde., 1844, Reprint, New York.

Lever, Th. (1870), Sermons, hg. v. Ed. Arber, London.

Luhmann, N. $\left(1989^{2}\right)$ : Legitimation durch Verfahren, Frankfurt/M.

Mason, R. A. (1982), Rex Stoicus: George Buchanan, James VI and the Scottish Polity, in: New Perspectives on the Politics and Culture of Early Modern Scotland, hg. von J. Dwyer et al., Edinburgh, S. 9-33.

Mayer, Th. F. (1989), Thomas Starkey and the Commonweal. Humanist Politics and Religion in the Reign of Henry VIII, Cambridge u. a. 
Mayer, Th. F. (1992), Nursery of Resistance: Reginald Pole and his Friends, in: Political Thought and the Tudor Commonwealth. Deep Structure, Discourse and Disguise, hg. v. P. A. Fideler/Th. F, Mayer, London/New York, S. 50-74.

More, Sir Thomas (1952), Sir Thomas Mores Utopia, übers. v. Ralph Robynson (1551), hg. v. Collins, J. Churton, Oxford.

Murray, J. A.H. (1893), A New English Dictionary on Historical Principles, 2 Bde., Oxford.

Ottow, R. (2000), Commonwealth. Konturen eines frühneuzeitlichen politischen Diskursbegriffs, in: Politische Vierteljahresschrift, 41.Jg., 2000, S. 76-103.

Parker, H. (1999), The Case of Shipmony Briefly Discoursed, 1640, in: The Struggle for Sovereignty. Seventeenth-Century English Political Tracts, Bd. 1, S. 93-125.

Parker, H. (1934), Observations upon some of his Majesties late Answers and Expresses, 1642, in: Tracts on Liberty in the Puritan Revolution. 1638-1647, hg. v. W. Haller, 3 Bde., New York, 1934, Bd. 2, S. 167-213.

Peltonen, M. (1995), Classical Humanism and Republicanism in English Political Thought, 1570 1640, Cambridge.

Ponet, J. (1639), A Short Treatise of Politicke Power, and of the true obedience which Subjects owe to Kings and other civill Governours, printed in the year 1556 (anon.), and now reprinted, o.O.

Raleigh, Sir Walter (1628), The Prerogative of Parliaments in England: proved in a Dialogue (pro and contra) betweene a Councellour of State, and a Iustice of Peace, Middelburge.

Scott, Th. (1973), Workes (The Workes of the Most Famous and Reverend Divine Mr. Thomas Scot, Batchelor in Divinitie, sometimes Preacher in Norwich), Utrick, 1624, Reprint, Amsterdam/New York.

Starkey, D. (1986), Which Age of Reform?, in: Revolution Reassessed. Revisions in the History of Tudor Government and Administration, hg. v. Chr. Coleman/D. Starkey, Oxford, S. 13-27.

Starkey, Th. (1989), A Dialogue between Pole and Lupset, hg. v. Th. F. Mayer, London.

Walzer, M. (1972), The Revolution of the Saints. A Study in the Origins of Radical Politics, New York.

Wootton, D. (Hg., 1986), Divine Right and Democracy. An Anthology of Political Writing in Stuart England, Harmondsworth. 
